\title{
Temperature-dependent energy budget of an Arctic Cladoceran, Daphnia middendorffiana
}

\author{
PEDER M. YURISTA* \\ Department of Biology, University of Michigan, Ann Arbor, Michigan, U.S.A.
}

\section{SUMMARY}

1. Global change models predict the greatest impact in climate to occur in the northern polar region. Change in temperature will alter individual metabolism and has the potential to change community structure to an unknown degree.

2. The temperature-dependent energy budget of Arctic Daphnia middendorffiana was investigated by measuring respiration rates, ingestion rates and assimilation rates. The scope for growth and reproduction was determined and compared with data from the literature for a clone of Daphnia pulicaria collected in the temperate zone.

3. A difference was observed between the Arctic species and the temperate zone clone in both temperature tolerance, and the energy available for growth and reproduction at various temperatures. A low availability of energy for growth and reproduction indicated that life history patterns as well as physiological mechanisms are important in allowing D. middendorffiana to exist successfully in Arctic environments.

4. The lower available energy for growth compared to Daphnia clones from temperate zones may be detrimental to $D$. middendorffiana, which might have to compete with species expanding their range under the predicted temperature increase for Arctic regions.

Keywords: Arctic zooplankton, bioenergetics, Daphnia, metabolism, temperature

\section{Introduction}

Abiotic factors such as the thermal environment are of central importance to many organisms (Andrewartha \& Birch, 1984). In particular, aquatic vertebrates, invertebrates and plants are predominantly ectothermic, and strongly influenced by the temperature and thermal conductivity of the environment. These ectothermic organisms are subject to changing physiological rates as the thermal environment changes because biological reactions vary with temperature. A variety of mechanisms allow an ectotherm some control of the regulation of its physiological state within normal temperature ranges (Hochachka \& Somero, 1984; Prosser, 1991). Metabolic processes become limited through reversible inactivation of

${ }^{*}$ Correspondence and present address: Peder M. Yurista, Hancock Biological Station, Murray State University, Murray, Kentucky 42025-0009, U.S.A. E-mail: peder.yurista@murraystate.edu enzymes (second-order temperature effects) outside the usual temperature range for any species. As temperatures become stressful, organisms either avoid the detrimental conditions (e.g. life history patterns and diapause stages) or else may not survive. Temperature affects both the physiology and life history of organisms.

Observed patterns in the distribution and occurrence of organisms is often explained by temperature. Thermal range and tolerance vary between species (e.g. eurytherm, cold stenotherm and warm stenotherm), and as a result, the geographical distribution of zooplankton and seasonal occurrence are often temperature correlated. Additionally, the outcome of competitive interactions between species has been shown to depend on temperature (e.g. Park, 1954). Competitive abilities such as running or swimming speed are maximized at specific temperatures (Webb, 1978; Stevens, 1979; Hertz, Huey \& Nevo, 1982; DeMott, 1989) and reduced at others. Competitive advantage, resulting from an organism's abilities being better suited to the thermal environment, may 
favour one species over another (Allan, 1977; Schwartz, 1984; Bengtsson, 1987; DeMott, 1989).

Energy intake and expenditure are ultimately responsible for the success of an organism in a community. A net positive energy budget for growth and reproduction is required for a species to persist in any thermal environment. The energy available to an organism for maintenance, growth and reproduction is dependent on several processes. Factors such as temperature alter the processes of energy intake (Burns, 1969; Geller, 1975), assimilation (Lampert, 1977b) and respiration losses (Kobayashi, 1974; Yurista, 1997), and therefore, the energy budget of an organism. The effect of temperature on assimilation and available energy affects the growth and reproduction of an organism, and ultimately, the components of the ecosystem which are linked through competition, predator-prey interactions or indirect links.

The present study focused on the energy budget of the Arctic Daphnia middendorffiana, a freshwater cladoceran. Ingestion, assimilation and respiration measurements were made under a wide range of temperatures to investigate the effect of temperature on energy available for growth and reproduction. A model based on the mechanisms of enzyme kinetics was used to describe the effect of temperature on whole organism processes. The resulting temperaturedependent budget was compared to the work of Lampert (1977a,b,c) for the energy budget of a clone of Daphnia pulex (later identified as D. pulicaria; Lampert, 1981) from the temperate zone. Methods similar to Lampert (1977a) were followed in the present study. The importance of physiology and life history were considered for the geographical distribution of these two Daphnia species.

\section{Methods}

Daphnia middendorffiana were collected at the Toolik Lake Long-Term Ecological Research (LTER) area for both laboratory and field measurements. The Toolik LTER (O'Brien, 1992) is located in Northern Alaska, U.S.A., on the foothills of the North Slope of the Brooks Mountain Range $\left(68^{\circ} 38^{\prime} \mathrm{N}, 149^{\circ} 38^{\prime} \mathrm{W}\right)$. Daphnia for laboratory experiments were transported to Ann Arbor, Michigan, U.S.A., and placed in culture at $12{ }^{\circ} \mathrm{C}$ with continuous lighting $\left(\approx 300 \mu \mathrm{E} \mathrm{m}^{-2} \mathrm{~s}^{-1}\right)$. Water used in culturing D. middendorffiana was obtained from Third Sister Lake, Washtenaw County, MI, U.S.A. The water was filtered with GF/F Whatman glass fibre filters (Whatman Inc., Clifton, NJ) and diluted to a conductivity of less than $\approx 200 \mu \mathrm{S} \mathrm{cm}^{-2}$, which is similar to the more dilute ponds and lakes of the Toolik region. Stock cultures of D. middendorffiana were fed mainly Chlamydomonas reinhardtii ad libitum and augmented with Cryptomonas ozolini. The Chlamydomonas and Cryptomonas were batch cultured in WC medium (Guillard \& Lorenzen, 1972). One half of the culture was removed every 2-3 days to feed the D. middendorffiana and fresh medium added to the algal culture. New cultures were started weekly to ensure a good supply of log-phase algae.

The energy content of $D$. middendorffiana was determined with length-weight regressions and elemental analysis $(C, N$ and $P$ ). Length-weight regressions were constructed for $D$. middendorffiana from the stock cultures and several populations collected from lakes in the vicinity of Toolik. Daphnia middendorffiana were measured to the nearest $0.02 \mathrm{~mm}(\times 40)$ from the centre of the eye to the base of the tail spine, and placed on aluminium boats which had been rinsed, dried $\left(24 \mathrm{~h}\right.$ at $\left.50{ }^{\circ} \mathrm{C}\right)$ and tared. The D. middendorffiana were dried for $24 \mathrm{~h}$ at $50{ }^{\circ} \mathrm{C}$, cooled and placed in a desiccator, and weighed on a Cahn electrobalance (Orion Research Inc., Beverly, MA) to the nearest microgram. The lengths and weights were logtransformed and a linear regression analysis was performed using SYSTAT (Wilkinson, 1990). Carbon, nitrogen and phosphorous contents of $D$. middendorffiana were determined from animals in stock cultures fed ad libitum, and animals were collected from ponds and lakes in the vicinity of Toolik Lake. The animals were measured for length, dried at $50{ }^{\circ} \mathrm{C}$ for $24 \mathrm{~h}$ on acid-washed Teflon disks, and weighed on a Cahn electrobalance to the nearest microgram. Carbon and nitrogen content were analysed on a Perkin Elmer $2400 \mathrm{CHN}$ analyser (Perkin-Elmer, Norwalk, CT) and phosphorous was determined from animals that were digested with persulphate and analysed using the molybdate method (Wetzel \& Likens, 1991).

Ingestion and assimilation rates were measured using radio-labelled cultures of Chlamydomonas. The Chlamydomonas was labelled by adding 20 or 40 $\mu$ Curies of ${ }^{14} \mathrm{C}-\mathrm{Na}_{2} \mathrm{CO} 3$ to algae in a screw-cap, 500$\mathrm{mL}$ Pyrex culture bottle. The algae were allowed to take up ${ }^{14} \mathrm{C}$ for $36-48 \mathrm{~h}$. The radio-labelled algal stock was centrifuged and re-suspended in either fresh 
unlabelled medium or filtered lake water at least three times to separate the algae cells from the labelling medium. After the final separation and re-suspension, the algae concentration was measured on a fluorometer $(100 \mu \mathrm{L}$ DCMU added; Slovacek \& Hannan., 1977). Samples of the algal stock were collected for determination of specific activity.

Size-specific ingestion rates for D. middendorffiana were measured at several food levels and temperature treatments. Food levels ranged from 0.088 to $3.2 \mathrm{mg} \mathrm{C} \mathrm{L} \mathrm{L}^{-1}$ and temperatures from 3.5 to $20^{\circ} \mathrm{C}$. Animals were acclimatized to each temperature for more than 2 weeks ( 3 months at $3.5^{\circ} \mathrm{C}$ ) in a walk-in culture room $\left( \pm 0.5^{\circ} \mathrm{C}\right)$ with ad libitum food. The $D$. middendorffiana were transferred to unlabelled food at the treatment concentration the evening prior to the measurement. Each measurement consisted of placing $\approx 50$ animals, which were evenly distributed in size from neonates to adults, in a $300-\mathrm{mL}$ BOD with labelled Chlamydomonas. The treatments were incubated for 6-20 min depending on temperature and food levels, with the longer incubation times at low temperatures and food levels. At the conclusion of the incubation period, the animals were collected on a nylon mesh, rinsed with filtered lake water, measured to the nearest $0.02 \mathrm{~mm}$ on a dissecting scope, and placed in individual scintillation vials with premeasured tissue solubilizer designed for $\mathrm{CO}_{2}$ retention (TS-2, Research Products International Corp., Mount Prospect, IL). The ingestion rates at each treatment were analysed using non-linear regressions (SYSTAT) (Wilkinson, 1990) of an allometric relationship $\left(\mathrm{aL}^{\mathrm{b}}\right)$. A modified Michaelis-Menton relationship (Ratkowsky, 1986) was used to describe the functional response to different food concentrations. The final ingestion model was based on size, functional response and temperature (Sharpe \& DeMichele, 1977).

The assimilation rates of D. middendorffiana were determined with radioactive tracers (Lampert, 1977a). Using radiotracers to determine assimilation rates depends on the animals having a full gut (Lampert, 1975, 1977a). Preliminary experiments were conducted to determine the gut filling time of D. middendorffiana at both low food levels $\left(0.175 \mathrm{mg} \mathrm{C} \mathrm{L}^{-1}\right)$ and temperatures $\left(3.5\right.$ and $\left.12{ }^{\circ} \mathrm{C}\right)$. A series of incubations were stopped at 20-min intervals over a period of $160 \mathrm{~min}$ to determine the gut filling time. Measurements were replicated on additional days. A second series of measurements were stepped at one hour increments over $7 \mathrm{~h}$ to determine a suitable grazing period for a clear signal from assimilation above that of the gut contents. At $12{ }^{\circ} \mathrm{C}$ and $0.175 \mathrm{mg} \mathrm{C} \mathrm{L}^{-1}$, gut filling time was $\approx 60 \mathrm{~min}$ (Fig. 1). At $3.5^{\circ} \mathrm{C}$, the gut filling time was less distinct, but less than $2 \mathrm{~h}$ (Fig. 1). The second set of measurements indicated that up to five hours was appropriate to obtain strong signals at food levels of $0.175 \mathrm{mg} \mathrm{C} \mathrm{L}^{-1}$ and $12{ }^{\circ} \mathrm{C}$. The treatment times were adjusted to 2 and $7 \mathrm{~h}$ for assimilation measurements at low food and temperature treatments. At higher temperatures of 16 and $20^{\circ} \mathrm{C}$, the incubation times were 1 and $3 \mathrm{~h}$, as used by Lampert (1977a).

The D. middendorffiana for assimilation measurements were sorted into a known size class and acclimatized to the experimental food conditions the night prior to the experiment. A single size class of
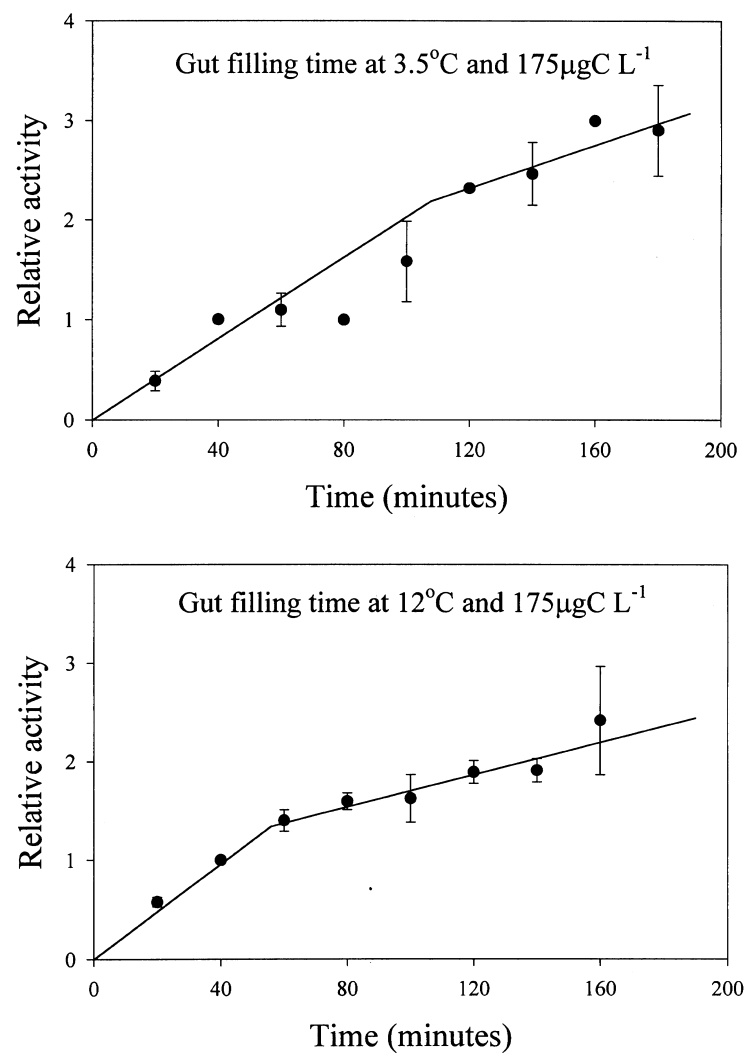

Fig. 1 Gut filling time of adult Daphnia middendorffiana at $0.175 \mathrm{mg} \mathrm{C} \mathrm{L} \mathrm{L}^{-1}$ food levels and (a) $3.5^{\circ} \mathrm{C}$ and (b) $12^{\circ} \mathrm{C}$. The $y$ axis shows relative activity compared to the 40-min treatment. The initial rate of increase in relative activity is a result of both ingestion and assimilation. The break in rate indicates the point at which the gut becomes full and the rate of increase in activity level of the animal beyond this point is caused by assimilation alone because ingestion is compensated for by egestion. 
animals $(2.1 \pm 0.1 \mathrm{~mm})$ was run for each assimilation measurement. Assimilation measurements were conducted with between eight and fifteen animals in volume-calibrated 60 - or $300-\mathrm{mL}$ BOD bottles with labelled Chlamydomonas. The number of animals and the bottle size were selected to minimize the depletion of algae during the course of the experiments (1-7 h) while maximizing the respiration signal. Six replicate bottles with animals were used for each assimilation measurement. Between two and four control bottles without animals were run simultaneously. At the completion of the $2 \mathrm{~h}(1 \mathrm{~h})$ grazing period, one half of the bottles with animals and controls were terminated. The remaining controls and treatments were terminated after $7 \mathrm{~h}(3 \mathrm{~h})$. Two food level treatments were used at each temperature and each measurement was replicated on at least one additional day: a low food level $\left(0.175 \mathrm{mg} \mathrm{C} \mathrm{L}^{-1}\right)$ below the incipient limiting level (ILL) and a high food level (0.575) near the ILL.

A closed system is required to account for several pools of carbon which are affected by the metabolism of the organism during the measurement of assimilation with ${ }^{14} \mathrm{C}$ (Lampert, 1975, 1977a). At the end of a grazing period, $10 \mathrm{~mL}$ from each BOD bottle was removed with a syringe and filtered through a 0.45 $\mu \mathrm{m}$ membrane filter into a vial containing $1 \mathrm{~mL}$ of $0.1 \mathrm{~N} \mathrm{NaOH}$ solution. This sample contained free ${ }^{14} \mathrm{CO} 2, \mathrm{H}^{14} \mathrm{CO} 3$ and ${ }^{14} \mathrm{DOC}$ (dissolved organic carbon) released by respiration and excretion of the animals and algae during the grazing period. A second 10-mL sample was filtered into $1 \mathrm{~mL}$ of $10 \%$ acetic acid to convert $\mathrm{H}^{14} \mathrm{CO} 3-{ }^{14} \mathrm{CO} 2$ and purged with air for $10 \mathrm{~min}$ to strip away ${ }^{14} \mathrm{CO} 2$. In this sample, the remaining ${ }^{14} \mathrm{C}$ was in the form of DOC. Two subsamples were collected and counted for activity from each of the $\mathrm{NaOH}$ - and acetic-acid-treated samples. The animals were collected on a nylon mesh screen and rinsed with filtered lake water. The animals were immediately heat-killed, measured for length and placed in individual scintillation vials with premeasured tissue solubilizer designed for $\mathrm{CO}_{2}$ retention (TS-2, Research Products International Corp. Mount Prospect, IL). The start times of each BOD bottle were staggered such that all operations could be completed promptly at the termination of each incubation period. All samples collected from a treatment were processed within $15 \mathrm{~min}$ following termination of the incubation. Control samples containing only labelled algae were processed in the same manner to determine algae respiration of ${ }^{14} \mathrm{C}$. Assimilation rates, including concurrent respiration of recent ${ }^{14} \mathrm{C}$ assimilation during the measurement period, were determined following Lampert (1977a).

Samples for liquid scintillation determination of ${ }^{14} \mathrm{C}$ were allowed to solubilize for $24 \mathrm{~h}$ before these were neutralized with acetic acid to reduce any contribution to background count rates from chemoluminescence. A scintillation cocktail for high water content (Ecolume) was added to all samples. Samples were counted on a Packard TR1900 LSC (Packard Instrument Company Meriden, CT) using external source quench correction algorithms to determine DPM.

Carbon, nitrogen and phosphorous content of algae were determined to quantify and compare the laboratory and field food resources in common terms. Laboratory cultures of log-phase algae and known chlorophyll concentration were collected on 13-mm AE (Gelman) glass fibre filters (Gelman, Ann Arbor, MI) which had been ashed $\left(450{ }^{\circ} \mathrm{C}\right.$ for $4 \mathrm{~h}$ ), rinsed and dried $\left(50{ }^{\circ} \mathrm{C}\right.$ for $24 \mathrm{~h}$ ). Field samples from lakes in the Toolik region were also collected on precombusted 13-mm AE filters, and analysed for carbon, nitrogen and phosphorous content. Five replicate samples of 180-300 mL were collected from a depth of $1 \mathrm{~m}$, and occasionally, from deeper waters. Samples were collected on several dates throughout a season. Two samples were analysed for carbon and nitrogen (CHN) and two were analysed for phosphorous.

Size-specific respiration rates for $D$. middendorffiana were measured using two different methods, polarographic microprobe techniques (Delieu \& Walker, 1972; Gnaiger \& Forstner, 1983) and microcoulometric techniques (Heusner, Hurley \& Arbogast, 1982; Heusner \& Tracy, 1984). The effect of temperature on respiration rate was determined with polarographic microprobe methods for adult $D$. middendorffiana at temperatures ranging from 3.5 to $30^{\circ} \mathrm{C}$. The effect of temperature on respiration was described with a mechanistic model for enzyme activity (Sharpe \& DeMichele, 1977; Schoolfield, Sharpe \& Magnuson, 1981; Yurista, 1997). Regression analysis for oxygen consumption as a function of temperature and dry weight was performed with non-linear techniques using systat (Wilkinson, 1990).

\section{Results}

The D. middendorffiana length-relationship was typical 


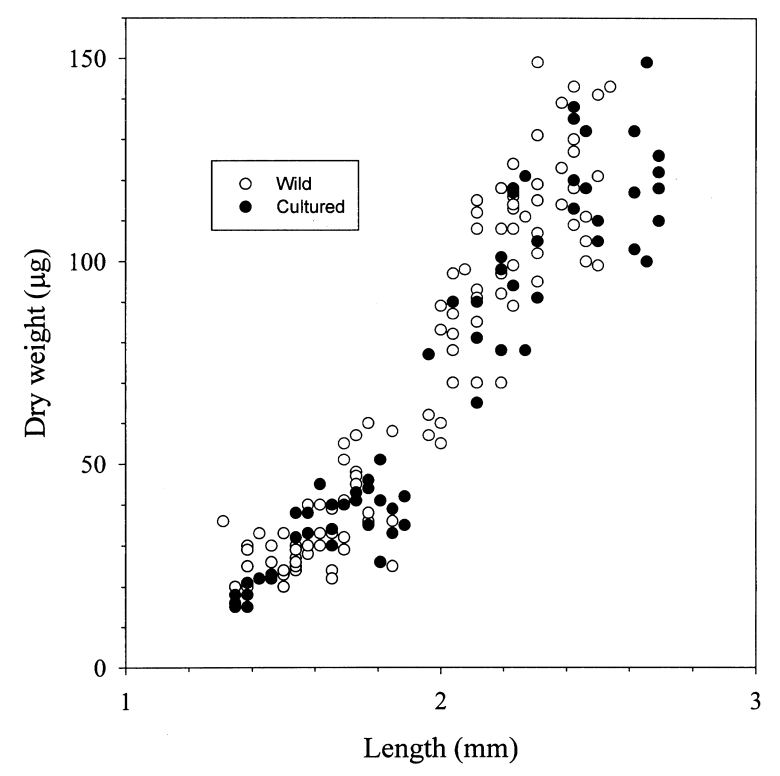

Fig. 2 A comparison of the length-weight relationship for Daphnia middendorffiana cultured at $12{ }^{\circ} \mathrm{C}$ with ad libitum food and field-collected animals: $(\bigcirc)$ field-collected animals and cultured animals.

of similar relationships for other Daphnia (Bottrell et al., 1976; Culver et al., 1985). Daphnia middendorffiana from Lake N1 raised in culture did not differ significantly in regression parameters from measurements on field-collected animals (Fig. 2, Table 1). However, there was a significant difference between measurements on clones in adjacent lakes from contemporaneous field collections (Table 1). The length-weight relationships for the clones from lakes $\mathrm{N} 1$ and NE9B were indistinguishable, whereas the clones from Lake S11 and animals cultured from Dam Pond were noticeably different. The S11 clone had a similar slope to N1 and NE9B, but a different constant. For animals used in the laboratory experiments, the exponent for a power relationship was found to be 2.150 and the coefficient was 12.13, corrected for retransformation (Bird \& Prairie, 1985) $\left(r^{2}=0.856, n=135, \mathrm{RMS}=0.008\right)$. The composition of D. middendorffiana was found to be $47 \% \mathrm{C}, 8 \% \mathrm{~N}$ and $1.4 \% \mathrm{P}$. There were small differences in composition between laboratory-cultured and field animals, and between clones from adjacent lakes (Table 2).

The elemental composition for cultured Chlamydomonas was $54 \% \mathrm{C}, 8.7 \% \mathrm{~N}$ and $1.1 \% \mathrm{P}$, in general indicating good food quality $(\mathrm{C}: \mathrm{N}=8.3, \mathrm{C}: \mathrm{P}=134)$. The carbon content of field resources ranged from low values of $0.18 \mathrm{mg} \mathrm{C} \mathrm{L}^{-1}$ to a maximum of 0.80 , with values generally between 0.3 and $0.4 \mathrm{mg} \mathrm{C} \mathrm{L}^{-1}$ (Fig. 3, Table 3). Carbon:nitrogen ratios were generally higher than cultured Chlamydomonas cultures (10-13), and carbon:phosphorous ratios were generally high with C:P ratios of over 200 and ranging up to 450 (Table 3).

Ingestion rates for individual treatments were described well by a standard allometric relationship, although the coefficient and exponent varied between treatments. The functional response of ingestion as a multivariate model with size and food concentration as independent variables was fit best with a modified Michaelis-Menton type relationship which had a concave shape with a maximal value (Fig. 4). The Michaelis-Menton model included an additional term which described the observed maximum with a depression in ingestion rates at high resource levels. The function is statistically well behaved (Ratkowsky, 1986). Ingestion rates peaked when ambient resources were around $0.5-0.7 \mathrm{mg} \mathrm{C} \mathrm{h}^{-1}$, the approximate incipient limiting level. The ingestion rates were noticeably depressed at high food levels under all temperature treatments. Size-specific ingestion rates varied with temperature and were lowest at $3.5^{\circ} \mathrm{C}$ with peak ingestion rates between 12 and $16^{\circ} \mathrm{C}$. The effect of temperature was modelled with a mechan-

Table 1 Length-weight relationship for Daphnia middendorffiana clones near the Toolik Lake Long-term Ecological Research camp. The regressions are based on $\log -\log$ transformation of length and weight data where: $\log$ [dry weight $(\mu \mathrm{g})]=\mathrm{a}+\mathrm{b}{ }^{*} \log [$ length (mm)]

\begin{tabular}{llllrr}
\hline & \multicolumn{2}{l}{ Length-weight relationship } & & \\
\cline { 2 - 4 } Clone & $\mathrm{a}$ & $\mathrm{b}$ & RMS & $n$ & $r^{2}$ \\
\hline Dam pond (cultured) & 1.078 & 2.150 & 0.0077 & 135 & 0.855 \\
N1 & 0.885 & 3.191 & 0.0058 & 103 & 0.920 \\
N1 (cultured) & 0.884 & 3.015 & 0.0074 & 64 & 0.921 \\
NE9B & 0.901 & 3.132 & 0.0081 & 131 & 0.935 \\
S11 & 0.607 & 2.841 & 0.0090 & 106 & 0.918 \\
\hline
\end{tabular}

(C) 1999 Blackwell Science Ltd, Freshwater Biology, 42, 21-34 
Table 2 Elemental composition of Daphnia middendorffiana from field and laboratory cultures. The results are shown as mean \pm SD

\begin{tabular}{|c|c|c|c|c|}
\hline \multirow[b]{2}{*}{ Daphnia clone } & \multicolumn{4}{|c|}{ Composition (\%) } \\
\hline & Carbon & Nitrogen & Phosphorus & $n$ \\
\hline Dam pond (cultured) & $45.0 \pm 4.6$ & $7.5 \pm 1.1$ & $1.4 \pm 0.2$ & 44 \\
\hline N1 & $43.7 \pm 5.4$ & $6.0 \pm 0.7$ & - & 24 \\
\hline N1 (cultured) & $49.3 \pm 3.4$ & $6.9 \pm 0.9$ & - & 22 \\
\hline NE9B & $43.8 \pm 4.3$ & $6.7 \pm 0.6$ & - & 36 \\
\hline NE9B (cultured) & $49.3 \pm 6.6$ & $9.1 \pm 1.4$ & - & 13 \\
\hline S11 & $39.3 \pm 2.7$ & $7.8 \pm 0.6$ & - & 13 \\
\hline
\end{tabular}

istic model based on enzyme inactivation (Sharpe \& DeMichele, 1977). The final regression model to describe size, functional response and temperature did a good job of explaining ingestion rates $\left(R^{2}=0.87\right.$, $n=1030)$. The model was limited to food levels less than $1.5 \mathrm{mg} \mathrm{C} \mathrm{L}^{-1}$ to avoid potential confounding factors from experiments at high food levels (see below). The restricted food level still encompasses levels encountered in ponds and lakes near the Toolik LTER site. The allometric exponent was 1.96 for size scaling in the multivariate model over all treatments.

Assimilation rates determined for $2 \mathrm{~mm}$ animals varied from a low of $0.09 \mu \mathrm{g} \mathrm{C} \mathrm{h}{ }^{-1}$ at $3.5^{\circ} \mathrm{C}$ and $0.175 \mathrm{mg} \mathrm{C} \mathrm{L}^{-1}$ to a high of $0.27 \mu \mathrm{g} \mathrm{C} \mathrm{h} \mathrm{h}^{-1}$ at $16^{\circ} \mathrm{C}$ and

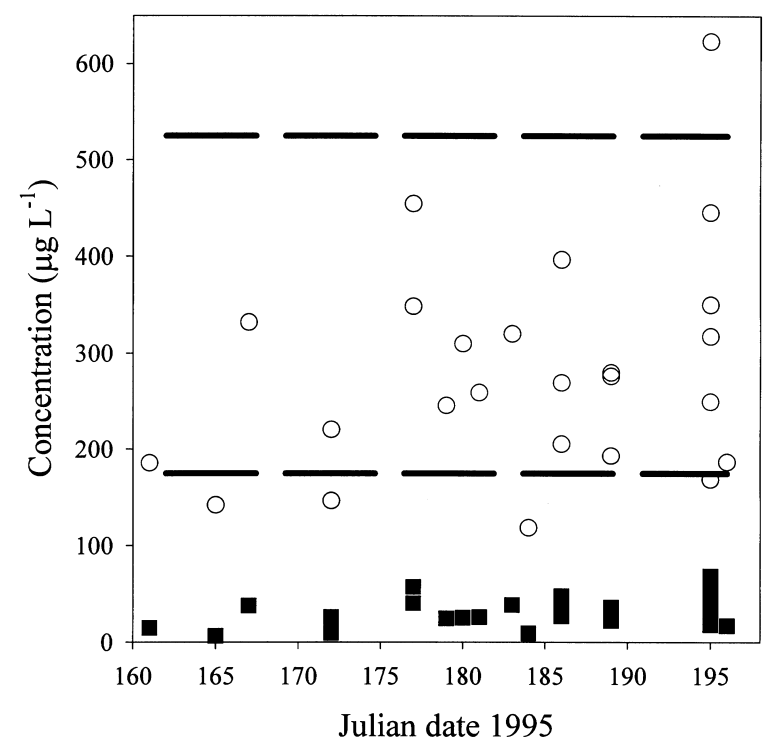

Fig. 3 Particulate organic matter in the ponds and lakes at the Toolik Lake Long-term Ecological Research site during the 1995 summer season: $(\bigcirc)$ carbon concentrations; $(\boldsymbol{\square})$ nitrogen concentrations, as determined by $\mathrm{CHN}$ analysis (Perkin-Elmer CHN 2400); and (-) treatment levels used in assimilation studies.
$0.525 \mathrm{mg} \mathrm{C} \mathrm{L}^{-1}$ (Fig. 5). The assimilation rate declined at the highest temperature $\left(20^{\circ} \mathrm{C}\right)$ from the peak value at $16{ }^{\circ} \mathrm{C}$. There was an increase in assimilation rate with an increase in food concentration at a given temperature; however, the increase in assimilation was not large or proportional to the relative change in food level. An assimilation efficiency (AE) was calculated from filtering rate determinations and assimilation rate measurements and found to depend on the food level. At the high food level, AE was 32\% $(25-38 \%)$, and at the low food level, this was $62 \%$ (56$67 \%$ ), and AE appeared to be unaffected by temperature (Table 4) (anova >0.4). This is probably a consequence of the longer gut passage time at lower food levels resulting in a longer time available for digestion and assimilation.

Respiration rates were found to have the sizespecific exponent 0.88 (Yurista, 1997), as typically found for temperate Daphnia (Richman, 1958). The respiration rate measured at temperatures up to $30{ }^{\circ} \mathrm{C}$ modelled well with the mechanistic relationship of Sharpe \& DeMichele (1977) (Yurista, 1997; Fig. 5).

\section{Discussion}

All the components of the energy budget, i.e. ingestion, assimilation and respiration, were temperature dependent for D. middendorffiana. The respiration

Table 3 Range in elemental composition of particulate organic material from field (depth $=1 \mathrm{~m}$ ) and laboratory cultures

\begin{tabular}{llll}
\hline Site & $\begin{array}{l}\text { Carbon } \\
\left(\mathrm{mg} \mathrm{L}^{-1}\right)\end{array}$ & $\begin{array}{l}\mathrm{C}: \mathrm{N} \\
(\text { atom:atom) }\end{array}$ & $\begin{array}{l}\text { C:P } \\
\text { (atom:atom) }\end{array}$ \\
\hline Dam pond & $0.10-0.17$ & $8.9-22.2$ & $204-314$ \\
NE9B & $0.19-0.42$ & $8.3-10.3$ & $229-438$ \\
Toolik Lake & $0.22-0.42$ & $8.9-10.4$ & $235-477$ \\
S11 & $0.26-0.59$ & $8.6-11.5$ & $337-453$ \\
Chlamydomonas & - & 7.7 & 130 \\
\hline
\end{tabular}

(c) 1999 Blackwell Science Ltd, Freshwater Biology, 42, 21-34 

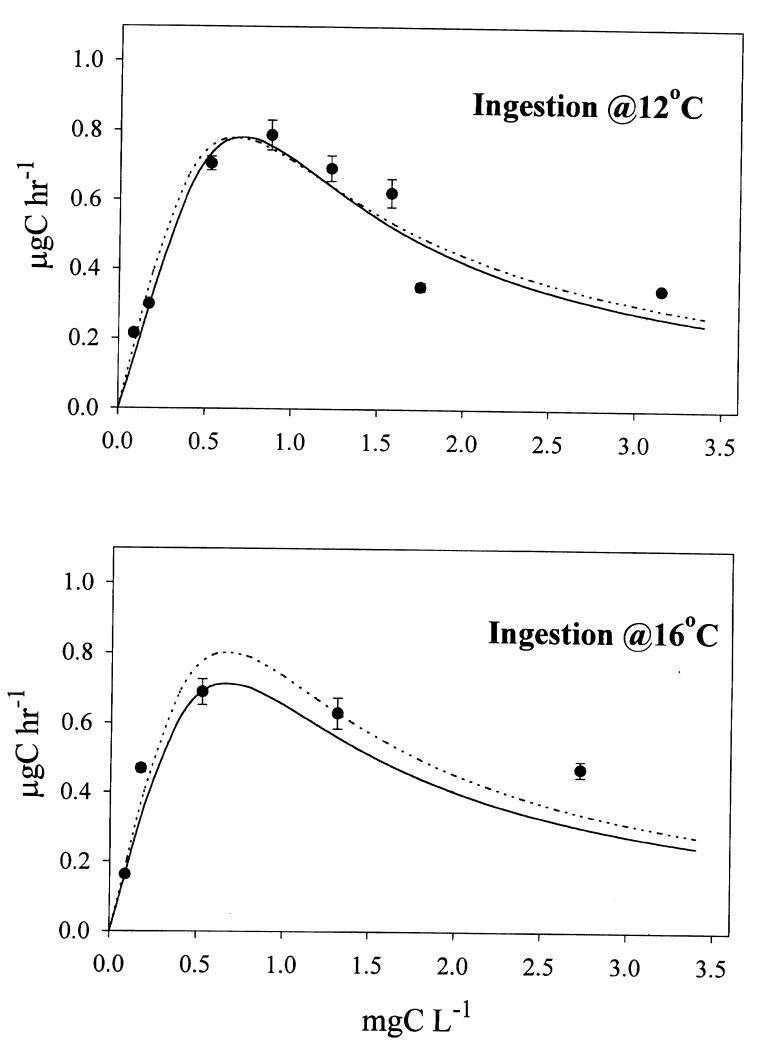

Fig. 4 Ingestion rates as a function of food concentration for two temperatures representative of field conditions: (a) $12{ }^{\circ} \mathrm{C}$ and (b) $16^{\circ} \mathrm{C}$. The data points and regressions are all normalized to animals of $2 \mathrm{~mm}$ in length. The data points are scaled allometrically to $2 \mathrm{~mm}$ using the individual regressions determined for each treatment with standard errors calculated from the scaled data. The solid line is the functional response determined at the treatment temperature using a modified Michalis-Menton regression. The dotted line is the overall ingestion model evaluated at the specified temperature for a 2$\mathrm{mm}$ animal: ingestion $=0.00268 *{ }^{\circ} \mathrm{K} * \exp [-4743(0.003509-1 /$ $\left.\left.{ }^{\circ} \mathrm{K}\right)\right] \mathrm{L}^{1.96 *} \mathrm{Food} /\left\{1+\exp \left[-23074\left(0.003541-1 /{ }^{\circ} \mathrm{K}\right)\right]\right\} *(1-$ $0.4114 *$ Food $+2.236{ }^{*}$ Food $^{2}$ ) where ${ }^{\circ} \mathrm{K}$ is degrees Kelvin, Food is $\mathrm{mg} \mathrm{C} \mathrm{L}^{-1}$ and $\mathrm{L}$ is $\mathrm{mm}$.

rate increased with temperature and peaked at about $28^{\circ} \mathrm{C}$ (Yurista, 1997). There was a wide thermal range in which respiratory enzymes remained fully active. The peak ingestion rate was found to occur between 12 and $16^{\circ} \mathrm{C}$, similar to that found by Chisholm, Stross \& Nobbs (1975) (Fig. 6). Assimilation was highest at $13-14{ }^{\circ} \mathrm{C}$ (Fig. 5). The effect of temperature on the resulting energy budget produced the most favourable effect on the scope for activity, growth and reproduction at $13-14{ }^{\circ} \mathrm{C}$ (Fig. 5).

Respiration was well described by a model which incorporated a description for the reversible inactiva- tion of enzymes (second-order effects) at both high and low temperatures (Yurista, 1997). The effect of temperature on the $D$. middendorffiana respiration was similar to the effect observed for temperate zone Daphnia. The Arctic D. middendorffiana is also a eurthytherm, but has regions at which respiration processes were adversely affected by temperatures about $5{ }^{\circ} \mathrm{C}$ lower than the temperate zone Daphnia.

Ingestion rates were size dependent, as has been found in previous studies (Bottrell et al., 1976). Size correction is important for removing covariance in bioenergetic budgets to ensure appropriate comparisons (Packard \& Boardman, 1987). An exponential allometric relationship was used for size scaling and incorporated into a multivariate model. Ingestion rates were scaled to a common length of $2 \mathrm{~mm}$ for subsequent comparisons.

A functional response to the available resources constrains the potential energy budget. Size-corrected

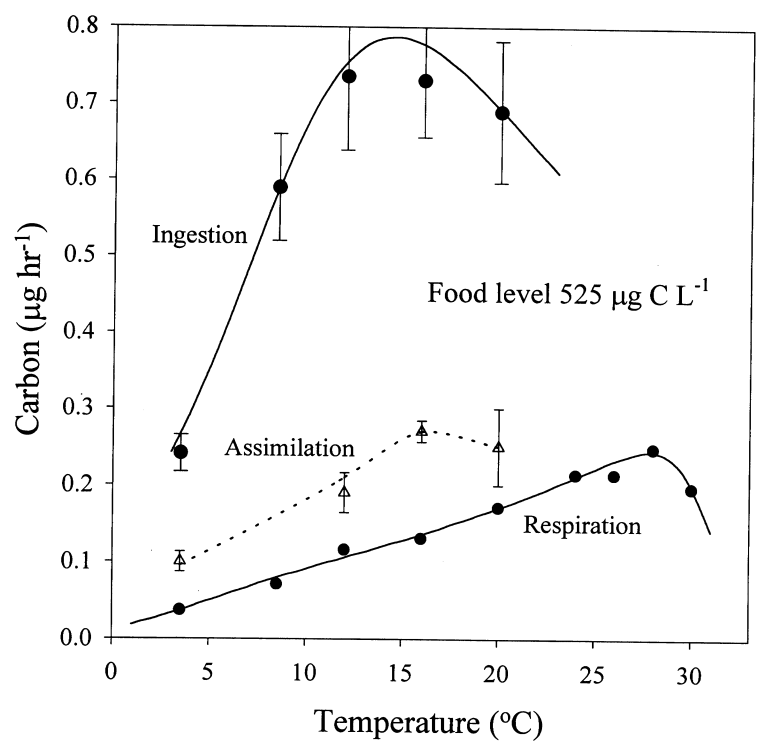

Fig. 5 Scope for growth at a food level of $0.525 \mathrm{mg} \mathrm{C} \mathrm{L}^{-1}$ as a function of temperature. Ingestion, assimilation and respiration variables are in carbon units and scaled to an animal length of $2 \mathrm{~mm}$. The ingestion rate data points are calculated for the specified temperature from the modified Michaelis-Menton regressions with standard errors from Monte Carlo simulations using the estimated parameter values and asymptotic errors. The ingestion rate regression is the fit to all data evaluated for 2$\mathrm{mm}$ animals and $0.525 \mathrm{mg} \mathrm{C} \mathrm{L}^{-1}$. The assimilation rates are measured values with the dotted line drawn by eye. The respiration rates (Yurista, 1997) are scaled using an RQ of 0.949 and conversions to carbon from Lampert (1984). 
Table 4 Assimilation efficiencies (AEs) for a 2-mm Daphnia middendorffiana calculated from ingestion rates ( $\mu \mathrm{g} \mathrm{C}{ }^{-1}$ ) and measured assimilation rates $\left(\mu \mathrm{g} \mathrm{C} \mathrm{h}^{-1}\right)(\mathrm{SD}, n)$. The ingestion rates are computed from the regression model fit to the entire data set (Fig. 4) with model components for allometry $\left(\mathrm{aL}^{\mathrm{q}}\right)$, functional response (Michaelis-Menton with quadratic term) and a mechanistic temperature function (Sharpe \& DeMichele, 1977)

\begin{tabular}{|c|c|c|c|c|c|c|}
\hline \multirow[b]{3}{*}{ Temperature $\left({ }^{\circ} \mathrm{C}\right)$} & \multicolumn{6}{|c|}{$\begin{array}{l}\text { Treatment level } \\
\left(\mathrm{mg} \mathrm{C} \mathrm{L}^{-1}\right)\end{array}$} \\
\hline & \multicolumn{3}{|l|}{0.175} & \multicolumn{3}{|l|}{0.525} \\
\hline & Ingestion & Assimilation & $\mathrm{AE}$ & Ingestion & Assimilation & $\mathrm{AE}$ \\
\hline 3.5 & 0.126 & $0.083(0.008, n=2)$ & $66 \%$ & 0.268 & $0.103(0.013, n=2)$ & $38 \%$ \\
\hline 12 & 0.354 & $0.213(0.006, n=3)$ & $60 \%$ & 0.755 & $0.190(0.026, n=3)$ & $25 \%$ \\
\hline 16 & 0.364 & $0.245(0.045, n=2)$ & $67 \%$ & 0.777 & $0.270(0.014, n=2)$ & $35 \%$ \\
\hline 20 & 0.324 & $0.180(n=1)$ & $56 \%$ & 0.691 & $0.210(0.0071, n=2)$ & $30 \%$ \\
\hline Average & & & $62 \%(5.4)$ & & & $32 \%(5.7)$ \\
\hline
\end{tabular}

functional response measurements at 12 and $16^{\circ} \mathrm{C}$ (Fig. 4) were characteristic of all temperature treatments conducted. In all temperature treatments, rates increased as food increased from low levels, and a peak ingestion rate of $\approx 0.7 \mu \mathrm{g} \mathrm{C} \mathrm{L}^{-1}$ was observed, followed by a depression in ingestion rate at very high food levels. The peak ingestion rate for many temperate zone Daphnia species is around $0.4 \mu \mathrm{g} \mathrm{C} \mathrm{L}^{-1}$ (Lampert, 1987), but this is dependent on the adaptation to ambient food levels (Lampert, 1994). In Lampert's

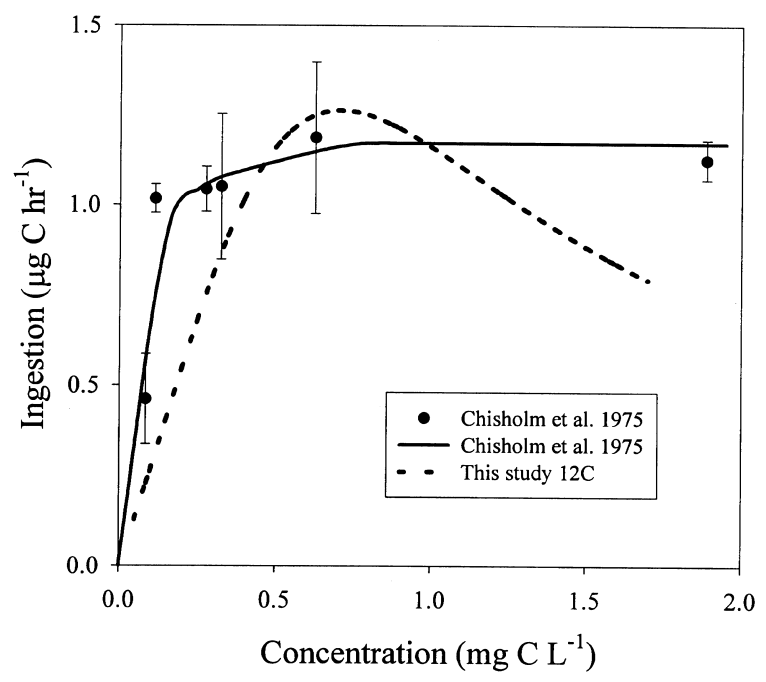

Fig. 6 Comparison of the ingestion rates in the present experiment with those of Chisholm et al. (1975) for Daphnia middendorffiana measured at $11{ }^{\circ} \mathrm{C}$ for $2.6-\mathrm{mm}$ animals. The results of Chisholm et al. (1975) have been re-plotted after converting cell counts to carbon using $65 \mathrm{pg} \mathrm{cell}^{-1}$ and assuming $50 \%$ carbon.
(1994) study, adaptation at low food levels increased ingestion rates to levels similar to the values measured here as a result of phenotypic plasticity in filter screen area. The filter rates and ingestion rates measured by Chisholm et al. (1975) for field animals are high and consistent with Lampert's (1994) results for low food acclimation, as are the results presented in the current study. The field results of Chisholm et al. (1975) in cell counts were converted to carbon with a conversion factor of $65 \mathrm{pg}$ cell $^{-1}$ and $50 \%$ carbon, and compared with the current laboratory measurements (Fig. 6). The highest food levels used in the present study are not characteristic of the Arctic region and are higher than those used in many published studies.

The final model for ingestion fits the data well $\left(R^{2}=0.87\right)$ and included parameters for allometry, functional response and a mechanistic model for the effect of temperature. The effect of temperature on the complex process of ingestion showed more constraint on an energy budget for $D$. middendorffiana than did the effect of temperature on respiration. This may be because ingestion involves more physiological complexity than the electron transport system for respiration. With added complexity one sub-process may have a larger limiting effect at low temperatures, while another may have larger limiting effect at high temperatures, thereby resulting in an overall greater limitation than would be experienced by any single enzymatic process. The overall process can still be described by an enzyme kinetic function, but the parameters are now effective values for the combined process rather than for the kinetics of any one specific enzyme (Sharpe \& DeMichele, 1977). 
Table 5 Assimilation efficiencies (AEs) calculated from the data set of Paloheimo et al. (1982), and regressions of Lampert (1977b) [assimilation $=0.844 * \mathrm{mg} \mathrm{C} /(\mathrm{mg} \mathrm{C}+0.164)]$ and Geller (1975) $\{$ ingestion $=\mathrm{mg} C *(0.029 * \mathrm{~T}-0.028) /[(0.30 * \mathrm{mg} \mathrm{C}+0.42) * 0.41]\}$ collected from the same laboratory clone

\begin{tabular}{|c|c|c|c|c|}
\hline Cells $\left(\mathrm{mL}^{-1}\right)$ & Assimilation $\left(\mathrm{mL} \mathrm{h}^{-1}\right)$ & Assimilation (cells $\mathrm{h}^{-1}$ ) & Ingestion (cells $\mathrm{h}^{-1}$ ) & $\mathrm{AE}$ \\
\hline Paloheimo et al. (1982) & 1.82 & 9104 & 11996 & 0.76 \\
\hline \multicolumn{5}{|l|}{5000} \\
\hline 10000 & 0.93 & 9334 & 15940 & 0.59 \\
\hline 25000 & 0.39 & 9647 & 19859 & 0.49 \\
\hline 50000 & 0.20 & 9891 & 21631 & 0.46 \\
\hline \multicolumn{5}{|c|}{$\begin{array}{l}\text { Geller (1975) and Lampert (1977b); } \\
2 \mathrm{~mm} \text { at } 20^{\circ} \mathrm{C}\end{array}$} \\
\hline Carbon $\left(\mathrm{mg} \mathrm{L}^{-1}\right)$ & Assimilation $\left(\mu \mathrm{g} \mathrm{C} \mathrm{h}^{-1}\right)$ & Ingestion & $\mathrm{AE}\left(\mu \mathrm{g} C \mathrm{~h}^{-1}\right)$ & \\
\hline 0.2 & 0.464 & 0.561 & 0.83 & \\
\hline 0.4 & 0.599 & 0.997 & 0.60 & \\
\hline 0.6 & 0.663 & 1.346 & 0.49 & \\
\hline 0.8 & 0.700 & 1.632 & 0.43 & \\
\hline 1.0 & 0.725 & 1.870 & 0.39 & \\
\hline 1.4 & 0.755 & 2.244 & 0.34 & \\
\hline 1.8 & 0.774 & 2.524 & 0.31 & \\
\hline
\end{tabular}

Filter screen adjustments may mediate the variation in the measured ingestion rates over temperature. For example, adjustments in filter comb area in response to stressful food conditions occur within a short period of time (Lampert, 1994). Increased filter comb area substantially enlarged ingestion rates (Lampert, 1994). It is also possible that temperature as a stress may induce changes in filter comb area. Daphnia middendorffiana were acclimated for more than 2 weeks and up to several months, which would provide ample time for changes in filter screen area to take place (Lampert, 1994). If temperature did influence filter screen area, this would confound the physiological interpretation of temperature effects in the enzyme model of Sharpe \& DeMichele (1977). Regions where second-order effects of temperature would reflect a departure from linearity on an Arrhenius plot could be modified as a result of morphological changes in filter comb area. This would be an effect which is not regulated by enzyme reactions during the ingestion process. The effect, if it exists, would confound the effect attributed to immediate physiological activity. The enzyme model accounts for the observed effect, but does not allow separation of variance into either enzyme activity or morphological plasticity.

Temperature affects the physical characteristics (viscosity) of the environment and changes in viscosity may also cause stress and affect changes in filter rates. The change in water viscosity is a factor of two across the temperature range of $1-25^{\circ} \mathrm{C}$, and the work expended in filter feeding depends on the pressure drop across the filter screens, which is a function of the water viscosity (Vanderploeg, 1994). From the present work, the effect of temperature on viscosity cannot be separated from the effect on enzyme kinetics.

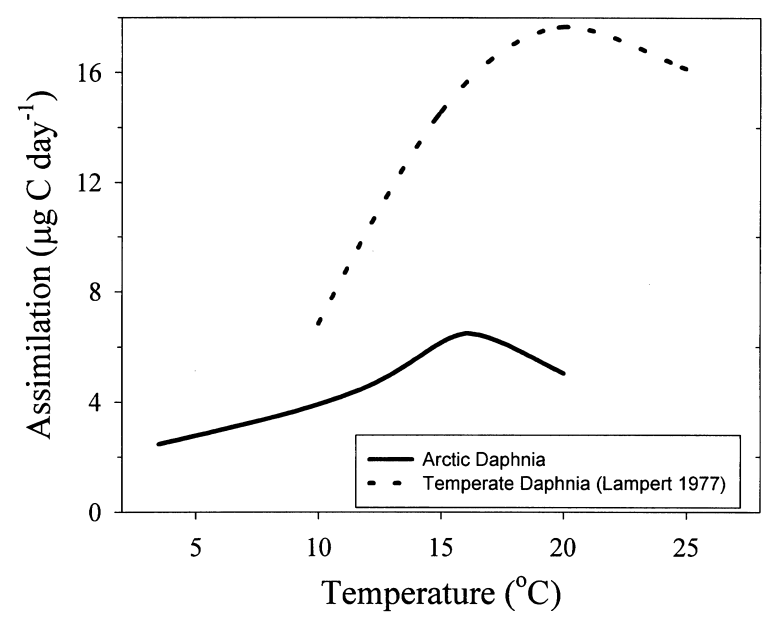

Fig. 7 Assimilation rates of a Daphnia pulicaria clone from a temperate zone (dashed line) as a function of temperature compared with Arctic D. middendorffiana assimilation (solid line). The temperate zone Daphnia assimilation data was derived from Lampert (1977c). 
Arctic Daphnia middendorffiana live in very oligotrophic waters and the highest food concentrations used in the present study of ingestion rates would be atypical in general. The observed depression of ingestion rates at the high levels in the current study needs additional explanation. Declines in ingestion rates at high food concentrations for other Daphnia have not been detected (e.g. Geller, 1975; Muck \& Lampert, 1984; Lampert, 1987). Daphnia have been shown to detect microscale differences in food quantity and quickly migrate to the source (Neary et al., 1992). Neary et al. (1992) also found that Daphnia avoided very high food levels. During the long acclimation period (overnight versus typical $0.5 \mathrm{~h}$ ) at high treatment levels, D. middendorffiana were unable to avoid the atypical levels, and alternatively, they may have suppressed ingestion rates. A second hypothesis is that animals may be able to distinguish and select a preferred distribution (Neary et al., 1992). If the food source is ubiquitous and high, then there is little need to filter at high rates during short periods of time to maximize intake, as is needed when food distributions are heterogeneous. A third hypothesis is that there are methodological problems with ingestion studies at high food levels and short incubation times. Lampert (1987) has suggested that animals placed in labelled food must first ingest the unlabelled food in their food groove before ingesting the labelled food in the experimental treatment. At the end of the experiment, when animals are rinsed off, the labelled food in the food groove may be lost. This will tend to underestimate ingestion rates, particularly for short time periods. The present study indicated that high ingestion rates were promoted at low and typical Arctic food levels, and were depressed for atypical high food levels.

The growth and reproduction of $D$. middendorffiana are functions of available energy. At a constant temperature, but under different availabilities of food, growth and reproduction were noticeably reduced under lower resource conditions (Yurista, 1997). In particular, there was a large difference in the numerical response of reproductive effort. Maximal energy (scope) in the present investigation was available to Arctic D. middendorffiana at about 13$14{ }^{\circ} \mathrm{C}$. The effect of temperature on scope is analogous to the effect of direct manipulation of food treatments at a fixed temperature. That the amount of available energy for growth and reproduction can be altered indirectly by changing temperature, as well as being altered directly by manipulation, suggests that temperature can be a factor in competitive outcomes. The larger scope at $13-14{ }^{\circ} \mathrm{C}$ than at other temperatures (Fig. 5) suggests that D. middendorffiana should do best at this temperature. This mechanistic explanation also provides insight to the classic results of Park (1954) with Tribolium beetles.

The temperature at which ingestion rates are maximized differs between the Arctic D. middendorffiana and temperate zone Daphnia (Lampert, 1987). This suggests that the effect of temperature has important consequences for the competitive abilities of the two species. The difference in abilities would suggest that one species should do better at the lower temperature and the other should do better at the higher temperature. Whereas ingestion does not account for the food resources eventually utilized, a more important element in an energy budget is the difference between ingested and egested material. The difference, i.e. assimilated material, may vary as a result of refractory material such as cellulose or silica frustules, or may depend on gut passage time (Geller, 1975; Lampert, 1987).

Assimilation efficiencies (AEs) were calculated for the two food treatment levels using the overall ingestion regression and the measured assimilation rates (Table 4). At the low food level, gut passage will be slower (Geller, 1975) and resources will remain in the gut longer, resulting in a greater potential for being digested and assimilated. At the high food level, gut passage will be more rapid and $\mathrm{AE}$ lower than at the low food level. Because the AE in the present investigation was relatively constant with temperature (Table 4), gut passage was probably the major factor in determining AE.

Opinion differs as to variability of AE. McCauley et al. (1990) regard AE to be constant, whereas Paloheimo, Crabtree \& Taylor (1982) provided evidence that it varies with food level. Additionally, Lampert's (1977b) and Geller's (1975) results for assimilation and ingestion rates, respectively, support variation of $\mathrm{AE}$ with food level (Table 5). The present study also supports the view that AE is correlated with food level. The mechanism suggested for this correlation is gut retention time. Gut retention time is inversely related to ingestion rate, while ingestion rate is a directly related to resource level. The AE will be relatively constant above the incipient lower level, but 
will increase as food levels decline below the incipient lower level (longer gut retention). Assimilation rates for resource levels other than those measured can be modelled as a function of ingestion rate multiplied by an $\mathrm{AE}$ expressed as a function of gut retention time (i.e. inverse correlation to food level). For the measurements of this study:

$$
\mathrm{AE}=17.1+7.93 /\left[\mathrm{mg} \mathrm{C} \mathrm{L}^{-1}\right]
$$

in per cent; $R^{2}=0.99, n=8$; two food levels and four temperatures. Computed AEs at alternate resource levels compare favourably with Paloheimo, Crabtree \& Taylor (1982), and Geller (1975) and Lampert (1977b) (Table 5).

A comparison of the energy budget determined for $D$. middendorffiana and that of D. pulicaria indicated a shift in the thermal response for the Arctic species (Fig. 7). The most favourable scope for 2-mm D. pulicaria (Lampert, $1977 \mathrm{a}, \mathrm{b}, \mathrm{c}$ ) occurred at $20^{\circ} \mathrm{C}$. Additionally, it is apparent from the energy budgets that the temperate species has a larger amount of energy available for growth and reproduction at warmer temperatures. This may be a significant factor in why D. middendorffiana is not generally found in temperate lakes, although many such lakes have a temperature range which would accommodate this animal. This may suggest that the temperate zone species are able to out-compete the Arctic species because of the larger amount of energy available to them at these temperatures.

A question arises as to why the Arctic species persist in the Arctic environment when the energy budget appears to favour the temperate zone species at temperatures down to $10^{\circ} \mathrm{C}$. The scope for the temperate zone species appears to be decreasing rapidly as temperature decreases below $10^{\circ} \mathrm{C}$. The observed trajectory for the scope of temperate zone Daphnia as a function of temperature may go below that of the Arctic zone Daphnia at common temperatures in Arctic ponds and lakes (e.g. 6-10 ${ }^{\circ} \mathrm{C}$; Miller, Prentki \& Barsdate, 1980). Lampert (1977c) had difficulty culturing sufficient temperate zone animals to investigate this temperature region. Both the trajectory of the scope and the fact that temperate zone Daphnia are difficult to culture at low temperatures because of their physiology suggest that the scope of Arctic zone Daphnia may exceed the temperate zone species under normal water tempera- tures in the Arctic. Another possible explanation may be life history adaptation in addition to physiological adaptation. The thermal environment of Arctic freshwater ponds and lakes is not substantially different from many temperate cool water systems; however, the length of the growing season is considerably reduced. The open water and summer stratification phase of Arctic lakes and ponds in the study area begins with ice out at the end of June or first part of July, and stratification starts to breakdown in midAugust when snow showers become routine again. The lakes are generally frozen over by mid-September. The time necessary to grow, reproduce and establish a diapause egg bank (DeStasio, 1989) for subsequent years may be 1-2 months. Adaptations which shorten the time to production of diapause eggs to ensure future generations will have an advantage. The life history of Arctic D. middendorffiana appears to have adaptations which suggest this may be the case. Firstly, Arctic D. middendorffiana are known to be facultatively asexual and produce viable diapause eggs without males (Hebert, 1987; present study). This effectively reduces the necessary time by one generation for the production of diapause eggs. Secondly, Arctic D. middendorffiana also invest in future generations prior to parthenogenic reproduction. In the present study, a large proportion of D. middendorffiana were observed to produce ephippia eggs first. Ephippia which were allowed to hatch and grow to adults under ad libitum food conditions produced viable ephippia prior to shifting to parthenogenic reproduction. Similarly, many parthenogenic neonates produced ephippia prior to reproducing parthenogenically. Stross, Miller \& Daley (1980) reported first generation D. middendorffiana in the ponds of Barrow, Alaska, U.S.A., with ephippia and also cited Swedish reports of similar occurrences. This early investment in future generations also appears to be a life history adaptation for short seasons.

Although these animals may have a favourable energy budget, the temperate zone species may not succeed at low temperatures for long periods of time. Lampert (1977c) experienced difficulty in raising $D$. pulicaria below $10{ }^{\circ} \mathrm{C}$, while Arctic D. middendorffiana form populations under ice (Stross et al., 1980). Although some temperate Daphnia are known to over-winter under ice, populations are usually not very abundant. The specific kinetic properties of homologous enzymes may make low temperatures a 
sub-optimal thermal region for temperate zone species. The Arctic D. middendorffiana is eurythermal, but its thermal range for respiration is shifted down about $5{ }^{\circ} \mathrm{C}$ compared to temperate zone Daphnia (Yurista, 1997). Arctic zone D. middendorffiana appear to have physiological adaptations to cooler temperatures. In addition, their success appears to be improved by life history factors which are advantageous for a short season.

Mechanistic formulation of temperature effects at the level of the individual provides predictive understanding in the biology of an organism. Models which predict in a manner consistent with known biology are recommended over empirical models. The use of mechanistic models allows us to probe temperature boundaries which are often of most importance in the survival of organisms (Moore, Folt \& Stemberger, 1996). The model formulation for temperature inactivation of enzymes may also be extended to complex levels of biological organization to describe the effect of temperature on processes or whole organisms (i.e. ingestion rates and development rates; Sharpe \& DeMichele, 1977). A mechanistic formulation of enzyme inactivation as a result of temperature provides us with an understanding which may be used at the population and community level to predict where organisms will do best, and where they may survive but competitor species may have an intrinsic advantage.

\section{Acknowledgments}

I would like to thank George Kling, Earl Werner, Hank Vanderploeg and David Allan for their support and constructive comments on the manuscript. I would like to thank William DeMott for his constructive review of the manuscript. I also would like to thank Mike Martin and Jim Teeri for use of lab equipment, and John O'Brien for helpful discussions. This work was supported in part by grants from the Rackham School for Graduate Studies, the Department of Biology, University of Michigan, and NSF grants 921175, 9400722, and 9553064.

\section{References}

Allan J.D. (1977) An analysis of seasonal dynamics of a mixed population of Daphnia, and the associated cladoceran community. Freshwater Biology, 7, 505-512.
Andrewartha H.G. \& Birch L.C. (1984) The Ecological Web. The University of Chicago Press, Chicago, IL.

Bengtsson J. (1987) Competitive dominance among Cladocera: Are single-factor explanations enough? Hydrobiologia, 145, 245-257.

Bird D.F. \& Prairie Y.T. (1985) Practical guidelines for the use of zooplankton length-weight regression equations. Journal of Plankton Research, 7, 955-960.

Bottrell H.H., Duncan A., Gliwicz Z.M., Grygierek E., Herzig A., Hillbricht-Ilkowska A., Kurasawa H., Larsson P. \& Weglenska T. (1976) A review of some problems in zooplankton production studies. Norwegian Journal of Zoology, 24, 419-456.

Burns C.W. (1969) Relation between filtering rate, temperature, and body size in four species of Daphnia. Limnology and Oceanography, 14, 693-700.

Chisholm S.W., Stross R.G. \& Nobbs P.A. (1975) Environmental and intrinsic control of filtering and feeding rates in Arctic Daphnia. Journal of the Fisheries Research Board of Canada, 32, 219-226.

Culver D.A., Boucherle M.M., Bean D.J. \& Fletcher J.W. (1985) Biomass of freshwater crustacean zooplankton from length-weight regressions. Canadian Journal of Fisheries and Aquatic Sciences, 42, 1380-1390.

Delieu T. \& Walker D.A. (1972) An improved cathode for the measurement of photosynthetic oxygen evolution by isolated chloroplasts. New Phytologist, 71, 201-225.

DeMott W.R. (1989) The role of competition in zooplankton succession. Plankton Ecology: Succession in Plankton Communities (ed. U. Sommer), pp. 195-252. SpringerVerlag, Berlin.

DeStasio B.T., Jr (1989) The seed bank of a freshwater crustacean: Copepodology for the plant ecologist. Ecology, 70, 1377-1389.

Geller W. (1975) Die Nahrungsaufnahme von Daphnia pulex in Abhangigkeit von der Futterkonzentration, der Temperatur, der Korpergroße und dem Hungerzustand der Tiere. Archiv für Hydrobiologie, 48(Suppl.), 47107.

Gnaiger D. \& Forstner H. (1983) Polarographic Oxygen Sensors. Springer-Verlag, Berlin.

Guillard R.R.L. \& Lorenzen C.J. (1972) Yellow-green algae with chlorophyllide c. Journal of Phycology, 8, 1014.

Hebert P.D.N. (1987) Genotypic characteristics of the Cladocera. Hydrobiologia, 145, 183-193.

Hertz P.E., Huey R.B. \& Nevo E. (1982) Fight versus flight: body temperature influences defensive responses of lizards. Animal Behaviour, 30, 676-679.

Heusner A.A., Hurley J.P. \& Arbogast R. (1982) Coulometric microrespirometry. American Journal of Physiology (Regulatory Integrative Comparative Physiology 12), 243, R185-R192. 
Heusner A.A. \& Tracy M.L. (1984) Coulometric measurement of oxygen consumption in insects. Measurement of Ion Transport and Metabolic Rate in Insects (eds T. J. Bradley and T. A. Miller), pp. 163-186. SpringerVerlag, Berlin.

Hochachka P.W. \& Somero G.N. (1984) Biochemical Adaptation. Princeton University Press, Princeton, NJ.

Kobayashi M. (1974) Oxygen consumption of Daphnia magna. Science Reports Niigata University, Series D, 11, 110.

Lampert W. (1975) A tracer study on the carbon turnover of Daphnia pulex. Verhandlungen Internationale Vereinigung für Theoretische und Angewandte Limnologie, 19, 2913-2921.

Lampert W. (1977a) Studies on the carbon balance of Daphnia pulex as related to environmental conditions. I. Methodological problems of the use of ${ }^{14} \mathrm{C}$ for the measurement of carbon assimilation. Archiv für Hydrobiologie, 48(Suppl.), 287-309.

Lampert W. (1977b) Studies on the carbon balance of Daphnia pulex as related to environmental conditions. II. The dependence of carbon assimilation on animal size, temperature, food concentration and diet species. Archiv für Hydrobiologie Suppl., 48, 310335.

Lampert W. (1977c) Studies on the carbon balance of Daphnia pulex as related to environmental conditions. III. Production and Production Efficiency. Archiv für Hydrobiologie Suppl., 48, 336-360.

Lampert W. (1981) Inhibitory and toxic effects of bluegreen algae on Daphnia. Internationale Revue der gesamte Hydrobiolgie, 66, 285-289.

Lampert W. (1984) The measurement of respiration. A Manual on Methods for the Assessment of Secondary Productivity in Fresh Waters (eds J. A. Downing and F. H. Rigler), pp. 413-468. Blackwell Scientific Publications, Oxford.

Lampert W. (1987) Feeding and nutrition in Daphnia. Memorie dell'Istituto Italiano di Idrobiologia, 45, 143192.

Lampert W. (1994) Phenotypic plasticity of the filter screens in Daphnia: adaptation to a low-food environment. Limnology and Oceanography, 39, 997-1006.

McCauley E., Murdoch W.W., Nisbet R.M. \& Gurney W.S.C. (1990) The physiological ecology of Daphnia: development of a model of growth and reproduction. Ecology, 71, 703-715.

Miller M.C., Prentki R.T. \& Barsdate R.J. (1980) Physics. Limnology of Tundra Ponds (ed. J. E. Hobbie), pp. 51-75. Dowden, Hutchinson and Ross, Stroudsburg.

Moore M., Folt C.L. \& Stemberger R.S. (1996) Consequences of elevated temperatures for zooplankton
D. middendorffiana

33

assemblages in temperate lakes. Archiv für Hydrobiologie, 135, 289-319.

Muck P. \& Lampert W. (1984) An experimental study on the importance of food conditions for the relative abundance of calanoid copepods and cladocerans. 1 . Comparative feeding studies with Eudiaptomus gracilis and Daphnia longispina. Archiv für Hydrobiologie, 66(Suppl.), 157-179.

Neary J., Cash K. \& McCauley E. (1992) Behavioral aggregation of Daphnia pulex in response to food gradients. Functional Ecology, 8, 377-383.

O’Brien W.J. (ed.) (1992) Toolik Lake. Hydrobiologia, 240, 1-269.

Packard B.C. \& Boardman T.J. (1987) The misuse of ratios to scale physiological data that vary allometrically with body size. New Directions in Ecological Physiology (eds M. E. Feder, A. F. Bennett, W. W. Burggren and R. B. Huey), pp. 216-236. Cambridge University Press, Cambridge.

Paloheimo J.E., Crabtree S.J. \& Taylor W.E. (1982) Growth model of Daphnia. Canadian Journal of Fisheries and Aquatic Sciences, 39, 598-606.

Park T. (1954) Experimental studies of interspecific competition. II Temperature, humidity and competition in two species of Tribolium. Physiological Zoology, 27, 177-238.

Prosser C.L. (1991) Environmental and Metabolic Animal Physiology. Wiley-Liss, New York, NY.

Ratkowsky D.A. (1986) Handbook of Nonlinear Regression Models. Marcel Dekker, New York, NY.

Richman S. (1958) The transformation of energy by Daphnia pulex. Ecological Monographs, 28, 273291.

Schoolfield R.M., Sharpe P.J.H. \& Magnuson C.E. (1981) Non-linear regression of biological temperature-dependent rate models based on absolute reaction-rate theory. Journal of Theoretical Biology, 88, 719-731.

Schwartz S.S. (1984) Life history strategies in Daphnia: a review and predictions. Oikos, 42, 114-122.

Sharpe P.J.H. \& DeMichele D.W. (1977) Reaction kinetics of poikilotherm development. Journal of Theoretical Biology, 64, 649-670.

Slovacek R.E. \& Hannan P.J. (1977) In vivo fluorescence determinations of phytoplankton chlorophyll a. Limnology and Oceanography, 22, 919-925.

Stevens E.D. (1979) The effect of temperature on tail beat frequency of fish swimming at constant velocity. Canadian Journal of Zoology, 57, 1628-1635.

Stross R.G., Miller M.C. \& Daley R.J. (1980) Zooplankton. Limnology of Tundra Ponds (ed. J. E. Hobbie), pp. 251296. Dowden, Hutchinson and Ross, Stroudsburg.

Vanderploeg H.A. (1994) Zooplankton particle selection and feeding mechanisms. The Biology of Particles in 
34 P. M. Yurista

Aquatic Systems (ed. R. S. Wotton), pp. 205-234. Lewis Publishers, Boca Raton, FL.

Webb P.W. (1978) Temperature effects on acceleration of rainbow trout, Salmo gairdneri. Journal of the Fisheries Research Board of Canada, 35, 1417-1422.

Wetzel R.G. \& Likens G.E. (1991) Limnological Analyses. Springer-Verlag, Berlin.

Wilkinson L. (1990) systat: The System for Statistics. systat, Inc., Evanston, IL.
Yurista P.M. (1997) The effect of temperature on the biology of two Cladocerans. Ph.D. Thesis, University of Michigan, Ann Arbor, MI.

(Manuscript accepted 18 December 1998) 